\title{
Entre centros e periferias: ciência, nação e região no estado do Amazonas
}

\author{
Between centers and peripheries: \\ science, nation and region in the state of Amazonas
}

\author{
Juliana Manzoni Cavalcanti \\ Bolsista de pós-doutorado Capes/PNPD, vinculada ao Programa de Pós-graduação em \\ História das Ciências e da Saúde/Casa de Oswaldo Cruz/Fiocruz. \\ jujumanzoni@yahoo.com.br
}

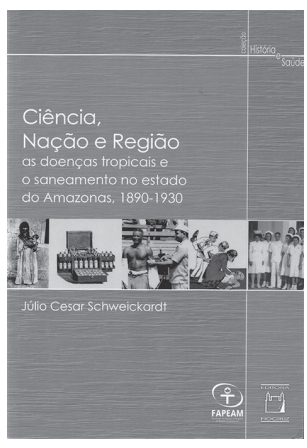

SCHWEICKARDT, Júlio Cesar. Ciência, nação e região: as doenças tropicais e o saneamento no estado do Amazonas, 1890-1930. Rio de Janeiro: Editora Fiocruz; Fapeam. 2011. 344p.
$\mathrm{O}_{q}^{\mathrm{in}}$ livro de Júlio Schweickardt se insere em um campo de estudos que busca compreender a história brasileira por meio das ações relacionadas à saúde e à ciência. O trabalho contribui para os debates historiográficos sobre ciência e nação, ao acrescentar uma nova perspectiva pela análise da variável regional. Desse modo, amplifica as discussões sobre construção da nacionalidade, aproximando-se dos debates sobre integração nacional, ao mostrar que as ações de saúde pública no estado do Amazonas buscavam não apenas a manutenção da saúde da população, mas a presença do Estado nos territórios nacionais longínquos.

Resultado da tese de doutoramento do pesquisador do Instituto Leônidas e Maria Deane, defendida na Casa de Oswaldo Cruz/Fiocruz em 2009, a obra foi construída a partir de grande variedade de fontes históricas. Isso poderia levar a uma análise pouco profunda do tema, porém, não foi o caso, pois o autor oferece uma contextualização primorosa, demonstrando grande capacidade de associação e interpretação das fontes, constituídas de notícias de jornais, trabalhos científicos, relatórios institucionais, documentos das comissões de saneamento etc.

Em relação às contribuições do âmbito teórico, o livro oferece mais uma amostra de como ocorriam as trocas científicas entre pesquisadores e médicos de diferentes países e regiões, ou seja, insere-se nas discussões sobre a circulação de práticas e saberes entre "centro" e "periferia". Alinhado às perspectivas surgidas na década de 1980 que se contrapunham à ideia de "difusão da ciência" do centro para a periferia, o autor demonstra que o Amazonas poderia representar a periferia em determinados aspectos, como, por exemplo, em relação às condições sanitárias, mas surgia como centro quando servia como local privilegiado para as investigações das doenças tropicais. 
Embora o autor aponte as expedições estrangeiras e as vindas da capital do país como momentos em que o Amazonas tornou-se o centro, não houve uma análise mais detalhada da relação entre tais cientistas e os pesquisadores nativos. É fato que o objetivo do trabalho não comportava análises mais profundas em relação às personagens. Uma incursão mais demorada na trajetória dos profissionais traria, no entanto, informações valiosas relativas à interação entre cientistas nativos e estrangeiros, demonstrando, por exemplo, até que ponto os trabalhos dos médicos nativos eram aceitos pelos cientistas europeus e da capital. Identificou-se apenas que "os médicos situados na 'periferia' seguiam padrões e procedimentos adotados no 'centro'" (p.110), o que revela uma visão ainda permeada pela ideia de preponderância de um local em detrimento de outro, a qual é invariavelmente propagada pelos estudos que adotam os termos centro e periferia. Um estudo mais aprofundado da produção de conhecimentos locais fica, portanto, para trabalhos futuros, que se beneficiarão largamente da obra de Schweikardt.

A narrativa do livro combina as histórias social e da ciência, demonstrando o desenvolvimento das ações de saúde pública no estado do Amazonas em consonância com as mudanças sociais mais amplas desencadeadas, principalmente, pelo início e pelo fim do ciclo da borracha. Na década de 1890, a extração de borracha representava considerável parte das exportações brasileiras, e os lucros advindos da atividade começaram a transformar a capital do estado com a construção de prédios luxuosos e com as obras públicas que lhe conferiram "uma aparência europeia" (p.39). Tal prosperidade diminuiu drasticamente a partir de 1913 com o fim do ciclo, enquanto as condições sanitárias, que ainda eram precárias, principalmente, no interior, agravaram-se seriamente. Em vista disso, a análise do autor se estende até o ano de 1930, pois as ações de saúde pública da década de 1920 foram direcionadas aos problemas agravados com o fim da era de prosperidade.

O livro está dividido em cinco capítulos, organizados cronologicamente a partir do terceiro, já que o primeiro capítulo oferece um panorama geral da inserção da Amazônia no contexto da medicina tropical e o segundo aponta as principais personagens e instituições da região. Esses capítulos iniciais servem como introdução aos demais, na medida em que chamam a atenção do leitor, primeiro, para a importância da região no que tange aos estudos em medicina tropical e, segundo, porque descrevem os principais atores locais envolvidos nas mudanças médico-sanitárias de Manaus e do estado do Amazonas.

No primeiro capítulo, o autor descreve o cenário de prosperidade de Manaus, decorrente do apogeu da exportação de borracha, para, em seguida, discorrer acerca do significado da região amazônica no imaginário sobre as áreas tropicais. Tal discussão introduz a análise relativa ao surgimento da medicina tropical e ao aparecimento do conceito de doenças tropicais, vistas pelo autor como doenças que impediam o estabelecimento dos europeus nas regiões tropicais. Por fim, expõe as controvérsias envolvidas no início da consolidação da malária e da febre amarela como doenças tropicais para, em seguida, descrever as pesquisas feitas no Brasil por cientistas brasileiros e estrangeiros.

O segundo capítulo nos apresenta um quadro dos médicos e cientistas atuantes na região, escolhidos pelo autor a partir de critérios como o engajamento com a saúde pública e com o trabalho científico, o envolvimento na criação e manutenção de instituições e o reconhecimento de seus pares. O autor relata, assim, como o médico Alfredo da Matta iniciou sua carreira como auxiliar no Serviço de Higiene do estado e chegou a professor da Faculdade 
de Medicina e diretor do Instituto Pasteur de Manaus, publicando ao longo dos anos obras importantes para a compreensão da nosologia da região. Schweickardt destaca Flora médica brasiliense, que descrevia 327 espécies e ganhou prêmios na Europa, Geografia e topografia médica de Manaus, confeccionada com objetivos sanitários, e Vocabulário amazonense: contribuição para o seu estudo, no qual apresenta os termos, a maioria de origem indígena, relativos a fauna, flora, geografia e alimentação.

No terceiro capítulo são abordadas as comissões de saneamento da cidade de Manaus que atuaram entre os anos de 1897 a 1899, 1904 a 1906, 1907 a 1913 e no ano de 1913. A descrição das ações sugeridas e promovidas pelas comissões mostra que os médicos da região tinham ciência dos novos conhecimentos e práticas da medicina tropical e da bacteriologia. Se na primeira comissão as práticas bacteriológicas ficaram apenas no papel, na segunda já estavam presentes nas propostas de saneamento, sendo incorporadas aos procedimentos de profilaxia na terceira e na quarta comissões. A partir do exame dos recursos destinados à profilaxia de cada doença, o autor percebe que os destinados à febre amarela ultrapassaram, proporcionalmente, quaisquer outros gastos, concluindo que isso tinha relação com a maior incidência da doença nos estrangeiros.

O quarto capítulo é dedicado ao exame de duas expedições do Instituto Oswaldo Cruz: a de 1910 comandada por Oswaldo Cruz nas obras da Estrada de Ferro Madeira-Mamoré e a de 1912-1913 chefiada por Carlos Chagas em municípios e seringais do interior do Amazonas. Segundo Schweickardt e Lima (2007), os relatórios de viagem dessas expedições têm grande significado histórico, porque reproduziram imagens e criaram representações sobre a região que passaram a constituir o imaginário social brasileiro. A análise dessas expedições procurou, portanto, apresentar os bastidores da criação das representações da Amazônia, dentre as quais se destaca a de que a região seria "um vasto cemitério".

No último capítulo, explora-se o contexto de criação do Serviço de Saneamento e Profilaxia Rural (SSPR) do estado do Amazonas (1921) até o ano de 1931, quando os objetivos das ações sanitárias não eram mais reverter os níveis de salubridade, agravados pelo término do ciclo da borracha. O período entre o fim do ciclo da borracha (1913) e a criação do SSPR não recebeu atenção, a não ser a reprodução de opiniões sobre a condição sanitária do estado. Tal ausência não compromete o encadeamento do livro, mas deixa o leitor curioso sobre o que ocorreu entre o início do declínio das atividades sanitárias e a criação do SSPR. Encontra-se, aqui, portanto, mais uma possível frente de pesquisa.

O livro é uma ótima contribuição aos trabalhos de história da saúde e da ciência, pois caracteriza aspectos da relação entre ciência e Estado e da circulação de práticas e saberes relacionados à saúde pública. Além disso, oferece um rico acervo de documentos e conhecimentos sobre a saúde pública no estado do Amazonas, abrindo novas propostas de investigação. Contribuiu também para a ampliação do conhecimento sobre as demais regiões brasileiras ao desviar-se do eixo Rio de Janeiro-São Paulo, o qual ainda é predominante nos estudos da área.

\section{REFERÊNCIA}

SCHWEICKARDT, Júlio César; LIMA, Nísia

Trindade. Os cientistas brasileiros visitam a

Amazônia: as viagens científicas de Oswaldo Cruz e Carlos Chagas (1910-1913). História, Ciências, Saúde - Manguinhos, v.14, supl., p.15-50. 2007. 